\title{
RELAGH - The challenge of having a scientific network in Latin America: An account from the presidents
}

\author{
Augusto Rojas-Martínez ${ }^{1}$, Alejandro Giraldo-Ríos ${ }^{2}$, Gerardo Jiménez-Arce ${ }^{3}$, Aída Falcón de Vargas ${ }^{4}$ \\ and Roberto Giugliani ${ }^{5}$ \\ ${ }^{1}$ Facultad de Medicina and Centro de Investigación y Desarrollo en Ciencias de la Salud, \\ Universidad Autónoma de Nuevo León, Monterrey, Mexico. \\ ${ }^{2}$ Facultad de Ciencias de la Salud, Universidad del Sinú, Montería, Colombia. \\ ${ }^{3}$ Sección Genética y Biotecnología, Escuela de Biología, Universidad de Costa Rica, San José, Costa Rica. \\ ${ }^{4}$ Unidad de Genética Médica, Universidad Central de Venezuela, Caracas, Venezuela. \\ ${ }^{5}$ Serviço de Genética Médica, Hospital de Clínicas de Porto Alegre, Porto Alegre, RS, Brazil.
}

\begin{abstract}
Latin America and the Caribbean region make up one of the largest areas of the world, and this region is characterized by a complex mixture of ethnic groups sharing lberian languages. The area is comprised of nations and regions with different levels of social development. This region has experienced historical advances in the last decades to increase the minimal standards of quality of life; however, several factors, such as concentrated populations in large urban centers and isolated and poor communities, still have an important impact on medical services, particularly genetics services. Latin American researchers have greatly contributed to the development of human genetics and historic inter-ethnic diversity, and the multiplicity of geographic areas are unique for the study of gene-environment interactions. As a result of regional developments in the fields of human and medical genetics, the Latin American Network of Human Genetics (Red Latinoamericana de Genética Humana - RELAGH) was created in 2001 to foster the networking of national associations and societies dedicated to these scientific disciplines. RELAGH has developed important educational activities, such as the Latin American School of Human and Medical Genetics (ELAG), and has held three biannual meetings to encourage international research cooperation among the member countries and international organizations. Since its foundation, RELAGH has been admitted as a full regional member to the International Federation of Human Genetics Societies. This article describes the historical aspects, activities, developments, and challenges that are still faced by the Network.
\end{abstract}

Keywords: Latin America and the Caribbean, human and medical genetics, international organization, research cooperation, education.

\section{Background}

Latin America and the Caribbean region is composed of 32 countries and Puerto Rico, an unincorporated territory of the United States. Twenty of these countries share a common history and culture resulting from the Iberian colonization in the $16^{\text {th }}$ century and are characterized by the use of the Spanish and Portuguese languages. The region covers an area of $21,069,501 \mathrm{~km}^{2}(14.1 \%$ of earth's land surface area) and is populated by 581.4 million people ( $8.3 \%$ of the world population), with approximately $79 \%$ of the people living in urban areas concentrated in the Atlantic coastal regions, the Central Valley of Mexico, the Andean moun-

Send correspondence to Augusto Rojas-Martínez. Centro de Investigación y Desarrollo en Ciencias de la Salud, Universidad Autónoma de Nuevo León, Carlos Canseco S.N., Col. Mitras Centro, Monterrey, 64460 Nuevo León, Mexico. E-mail: arojasmtz@gmail.com. tains, Central America and the main Caribbean islands; overall, this area has a per capita gross national income (GNI) of US\$ 8,981. This territory constitutes one of the largest linguistic and culturally cohesive regions in the planet and represents the $4^{\text {th }}$ largest economy in the world (Latin America and the Caribbean (LAC) Population Database, 2005; Almanaque Mundial 2013, 2012; The World Bank, 2013).

The Human Development Report 2013 of the United Nations Development Program showed that the majority of the countries in Latin America and the Caribbean have reached a Human Development Index (HDI) of 0.741, which is considered a high HDI; however, several countries in the area exhibit a medium HDI (Human Development Report, 2013). This index suggests that the population in the region has reached an acceptable quality of social welfare and acceptable medical services, including pre-natal 
and perinatal screening, fetal medicine, medical genetics services, and sophisticated molecular and genetics diagnostics laboratories; however, the region still suffers from important income inequalities and has the most unequal income distribution worldwide (Human Development Report, 2013). Important sub-regional differences exist in every country of the region, even in countries with a very high HDI. Health services are concentrated in the primary urban centers, and there is a substantial lack of primary healthcare centers in the rural areas to provide quality medical attention; additionally, almost no genetic services are available in several regions and countries (Penchaszadeh, 2004). As with the health systems, the universities and research centers are also located in the main metropoles; however, the region stills suffers from minimal financial resources for research, low academic-entrepreneurial interactions and small inter-academic cooperation to develop research. Nevertheless, several governments are starting to support research activities, and several institutions with welltrained scientists and sufficient infrastructure are performing genomic research, primarily in countries such as Brazil, Mexico, Argentina, and Chile.

The activities in the fields of human genetics and medical genetics in Latin America and the Caribbean began in the 1950-60s. Several original clinical descriptions of Beguez-Chédiak-Higashi syndrome (OMIM \#214500), Cantú syndrome (OMIM \#239850), congenital generalized hypertrichosis (OMIM \#307150), Grebe-Quelce-Salgado syndrome (OMIM \#200700), acheiropodia (OMIM \#200500), Yunis-Varon syndrome (OMIM \#216340), IVIC Syndrome (OMIM\#147750), odontotrichomelic syndrome (OMIM \#273400), and several camptodactyly associated syndromes, among others [Online Mendelian Inheritance in Man (OMIM)], were first described by Latin America geneticists; additionally, several regional hemoglobinopathies have been described and characterized. These scientists have also described notable genetic phenotypes clusters or large pedigrees for Huntington's disease in Maracaibo (Negrette, 1963), Laron syndrome in Ecuador (Berg et al., 1992), early-onset Alzheimer's disease in Colombia (Lopera et al., 1997), Jarcho-Levin syndrome in Puerto Rico (Cornier et al., 2004), twin births in Brazil (Tagliani-Ribeiro et al., 2012), and actinic prurigo in several American-aboriginal communities, among others. Latin American geneticists also established remarkable birth defect registries, including the Estudio Colaborativo Latino Americano de Malformaciones Congénitas (ECLAMC) by Dr. Eduardo Castilla in South America and the Registro y Vigilancia Epidemiológica de Malformaciones Congénitas Externas (RIVEMCE) by Dr. Osvaldo Mutchinick in Mexico. These registries are crucial for the understanding of several complex congenital diseases, such as orofacial clefts and neural tube defects, and several local studies have demonstrated that folic acid supplementation can help prevent neural tube defects. Several countries have national newborn screening programs, with very high coverage by comprehensive panels in Costa Rica, Chile, and Uruguay. The detection of congenital hypothyroidism has been effectively attempted by newborn screening programs in several Latin American countries. Population geneticists have greatly contributed to the genetic studies of the aboriginal and modern Latin American and Caribbean populations. Finally, for the research of complex prevalent diseases, such as diabetes, cardiovascular disorders, psychiatric diseases, birth defects, and cancer, and for pharmacogenomic studies, the region offers unique conditions that are not present in the rest of the world, including environmental diversity, ethnic diversity, population structure, and a high rate of environmental exposures. This scenery favors the study of gene-environment interactions, and several admixture studies have analyzed the genetic factors involved in complex phenotypes.

All of these developments and the promissing progress in the field of human and medical genetics inspired several of the founders and leaders of these disciplines in this region to create the Red Latinoamericana de Genética Humana (RELAGH) in the early 1990s, with the aim of creating a network for human genetics researchers, students, and practitioners in Latin America and the Caribbean; the goal of this network was to contribute to the development of collaborative projects for education, research and assistance, and to represent the region before the International Federation of Human Genetics Societies (IFHGS).

\section{The Foundation of RELAGH}

The idea of creating a Latin American Network of Human Genetics (RELAGH) arose during the IX International Congress of Human Genetics in 1996 in Rio de Janeiro, Brazil, at which the International Federation of Human Genetic Societies was created. Several Latin American societies of human and medical genetics applied for membership to the new organization. After establishing that the Executive Committee of the IFHGS would include representatives of societies in Europe, United States, Canada, Australia, and Asia as full members, this committee suggested that Latin America could form a regional representative group. In 1997, a meeting was held in San Juan de el Río, Queretaro, Mexico; at this time, representatives of the human genetics field from a dozen Latin American countries, and Dr. Marcus Pembrey, the IFHGS representative, organized RELAGH, stating that such a network would represent not only human genetics societies, but also persons in those countries that do not have associations or societies.

A meeting in 1999 in Buenos Aires, Argentina, primarily attended by ECLAMC members, resulted in the nomination of an Organizing Committee that consisted of representatives from Brazil, Argentina, and Mexico. Several difficulties were overcome in the following years; therefore, in Vienna, Austria, during the $10^{\text {th }}$ International 
Congress of Human Genetics in May 2001, RELAGH was formally established through the participation of the Presidents of five groups: the branch of Human Genetics of the Sociedad Argentina de Genética, the Sociedade Brasileira de Genética Médica, the Asociación Colombiana de Genética Humana, the Asociación Mexicana de Genética Humana, and the Sociedad Panameña de Genética Humana. Dr. José María Cantú (Mexico) was appointed the Acting President for two years, and he agreed to create an assembly to evaluate the proposed governing statutes of RELAGH and chose the first Board of Directors. Dr. Roberto Giugliani (Brazil) was proposed as the RELAGH operator. During the IFHGS meeting at the same Congress, RELAGH was accepted as a full member and part of its Executive Committee.

In 2003, a new Board of Directors was appointed during the Presidency of Roberto Giugliani (Brazil). This board decided to form an Executive Committee to address the practical activities of the young network. This committee was based in Porto Alegre, Brazil and was formed by Roberto Giugliani and Ursula Matte (Chairpersons). The primary goals for this period were to draft and propose the bylaws of the network; to consolidate RELAGH as a representative of Latin America in the IFHGS; to set up the network website and use it as the main communication tool between RELAGH members; to expand the RELAGH membership, and promote RELAGH as a hub for collaboration among human genetics groups in the Latin American region; and to organize the Latin American School of $\mathrm{Hu}-$ man and Medical Genetics (ELAG). Having achieved all of these goals, the RELAGH presidency was transferred to the new board of directors in 2006 (no business meeting was held in 2005). The Executive Committee decided to continue its activity and became the Organizing Committee of the ELAG, which has been a very successful course since 2005.

The bylaws of the network were initially established in March 2004 and modified in 2008 during the First Latin American Congress of Human Genetics in Cartagena, Colombia. Thereafter, RELAGH has been led by the following presidents: Dr. Alejandro Giraldo-Ríos (2006-2008), Dr. Gerardo Jiménez-Arce (Costa Rica, 2008-2011), and Dr. Augusto Rojas-Martínez (Mexico, 2011-2013); RELAGH is currently led by Dr. Aída Falcón de Vargas (Venezuela, 2013-2015).

\section{The Latin American School of Human and Medical Genetics (ELAG)}

Short courses in medical and human genetics are already offered to young students and professionals in North America (the Bar Harbor course on Mammalian Genetics) and Europe (The European School of Medical Genetics). Young researchers and professionals in Latin America should also be prepared to address the challenges of increased genetic applications in health sciences.

The aim of ELAG is to promote a one-week "state of the art" Human and Medical Genetics course that will expose a selected number of top-grade students to first rank researchers in the field. In addition to attending a strong teaching program, the students have the unique opportunity of discuss projects, techniques, clinical cases, and scientific issues with the faculty members. The participation of students and faculty members from several Latin American countries stimulates further cooperation between the groups inside the continent. During this course, new connections are created, and new opportunities are opened. The target audience includes PhD students, post-docs, and young physicians interested in the fields of human and medical genetics. The students are selected on the basis of a broad participation of Latin American countries and on their individual performance according to academic records, curriculum vitae, and recommendation letters. The ELAG faculty consists of top rank scientists from Latin America, North America and Europe who are invited to lead lectures and courses. On-site accommodations are an important point, as informal contact between students and faculty is one of the major goals of this initiative. Regarding the financing of ELAG activities, the organizers apply to governmental organizations, research funding agencies, and companies to obtain the financial support for the faculty expenses, including transport, accommodation and meals, and to grant a limited number of competitive fellowships to students. The organizers also encourage the national agencies of Latin American countries to grant fellowships to cover student expenses.

The first ELAG course was held in 2005, and this course has been repeated every year. With the exception of 2007, when it was held in Angra dos Reis (200 km from Rio de Janeiro), all of the courses have been held at Hotel Samuara in Rio Grande do Sul, Brazil. This hotel is located inside a natural park, $10 \mathrm{~km}$ from the city of Caxias do Sul and $100 \mathrm{~km}$ from Porto Alegre, and provides a perfect environment for the development of this activity. Each course has 70-75 students that come from 10-15 different Latin American countries and 25-30 faculty members from Latin America, North America, and Europe.

\section{Latin American Meetings of Human Genetics}

The first Latin American Congress of Human Genetics (CLAGH) was co-organized between RELAGH and the Asociación Colombiana de Genética Humana and was celebrated in Cartagena, Colombia in October 2008. The meeting was attended by human and medical geneticists and many students from almost all of the region. A workshop on laboratory standards, organized by Dr. JeanJacques Cassiman, in representation of the EurogenTest, was held to contribute to the understanding of quality assurance norms and ethical standards that have been established 
by this European organization. The meeting was a very successful effort to launch research and academic activities in the region. During the business meeting, the bylaws of the Network were modified, and the presidency was handed over to Dr. Gerardo Jiménez-Arce (Costa Rica).

The $2^{\text {nd }}$ CLAGH occurred in San José Costa Rica in May, 2011 and was co-organized by RELAGH and the Universidad de Costa Rica and the Colegio de Biólogos de Costa Rica, and was financed, in part, by the National Ministry of Science and Technology. The meeting began with a lecture by Dr. Judith Hall, president of IFHGS. During this event, the Universidad de Costa Rica granted the Doctor honoris causa title to Dr. Francisco M. Salzano (Brazil) for his contributions in the development of the Population Genetics in Latin America. Again, the EurogenTest Organization offered a workshop, which was conducted by Dr. Gert Matthijs. The Human Variome Project Organization (HVP) held a meeting, which was presided over by Dr. Richard G. Cotton, the founder of the project, to encourage the participation of Latin America in this project. During the business meeting, the RELAGH presidency was handed over to Dr. Augusto Rojas-Martínez (Mexico).

Due to the invitation of Dr. Cotton, an inter-institutional Mexican group created the first Latin American Node of the HVP in June 2012. The Node received financial support from the Centro de Investigación y Desarrollo en Ciencias de la Salud of the Universidad Autónoma de Nuevo León in Monterrey, in which the bioinformatics group coordinates the collection of relevant national data. A second HVP Node was launched in March 2013 in Venezuela, under the leadership of Dr. Aída Falcón de Vargas.

The $3^{\text {rd }}$ CLAGH was held in November 2012 in the Riviera Maya, Mexico. The meeting was co-organized by the Asociación Mexicana de Genética Humana, which also celebrated the $38^{\text {th }}$ Mexican Meeting of Human Genetics. The meeting was attended by more than 800 participants, including more than 70 lecturers by researchers from the USA, Europe, Australia, Latin America and the Caribbean and included the attendance of Dr. Stephen Lam, President of IFHGS. In addition to six plenary lectures, a total of six workshops, 11 symposia, 80 oral, and 293 poster presentations were contributed by researchers from almost all of the Latin America and Caribbean countries. These events covered the topics of medical genetics, cytogenetics, complex diseases, population genetics, molecular biology, genetic epidemiology, and cancer. A 3-day workshop on Public Health Genomics, financed by the Consejo Nacional de Ciencia y Tecnología (Mexico), was conducted as a preamble for the $3^{\text {rd }} \mathrm{CLAGH}$. This workshop introduced the concept of using genomic information for public health purposes to improve preventive care. Lecturers for this workshop included leading scientists from the fields of public health, medical genetics, human genomics, and bioinformatics from the USA, Europe,
Argentina, Brazil, and Mexico. The HVP held a special symposium to promote the creation of more HVP country nodes in the region. During this meeting, the General Assembly of RELAGH examined the status of the Network, including the rules for membership, and elections were performed to form the new Board. The Presidency was handed over to Dr. Aída Falcón de Vargas (Venezuela), and Dr. Lavínia Schüler-Faccini (Brazil) was elected as vice-president of the Network for the period of 2014-2015. This meeting showcased new technologies, including next generation sequencing and microarray platforms, that can facilitate genomic research studies of monogenic, chromosomal, and complex diseases, as well as made efforts to introduce these technologies into the clinic for diagnostic purposes.

\section{Challenges}

Despite the progress that has been made, the Network is presently consists of national associations, societies, and sections of human and medical genetics from 13 countries (Argentina, Brazil, Bolivia, Chile, Colombia, Costa Rica, Cuba, Ecuador, Mexico, Panama, Peru, Uruguay, and Venezuela). Associations from Nicaragua, and Paraguay declared their interest in joining RELAGH during the last meeting held in the Riviera Maya, and these associations will most likely be included during the current presidency. This interest implies that RELAGH should increase its efforts to network with the associations of several countries in Central America and the Caribbean.

Having decided since the very beginning to not collect fees from its members, RELAGH faces a continuous challenge in obtaining funding to support its activities. Obtaining funding has been accomplished with the help of the affiliated national societies, whose support has enabled RELAGH to conduct its meetings. However, more stable funding should be pursued to enable the development of projects that are aimed at establishing stronger connections between its members, such as regular newsletters, online educational projects, the maintenance of an updated database of research groups and services provided in the region, training/exchange programs, and other possibilities.

Finally, the integration of available human resources and infrastructure in the region remains a challenge. Although this ability may compensate for the lack of professional and laboratory services in several countries and regions, ignorance about resources, the lack of communication and logistic, and administrative limitations, such as courier services and national customs, still restrict efficient international cooperation. The implementation of national directories of medical genetics services and diagnostic laboratories may be a step forward in accomplishing these tasks, and the current presidency of the RELAGH is working towards this goal. 


\section{References}

Almanaque Mundial 2013 (2012) Editorial Televisa, S.A. de C.V. México, D.F., Mexico.

Berg MA, Guevara-Aguirre J, Rosenbloom AL, Rosenfeld RG and Francke U (1992) Mutation creating a new splice site in the growth hormone receptor genes of 37 Ecuadorean patients with Laron syndrome. Hum Mutat 1:24-32.

Cornier AS, Ramírez N, Arroyo S, Acevedo J, García L, Carlo S and Korf B (2004) Phenotype characterization and natural history of spondylothoracic dysplasia syndrome: A series of 27 new cases. Am J Med Genet A 128A:120-126.

Lopera F, Ardilla A, Martínez A, Madrigal L, Arango-Viana JC, Lemere CA, Arango-Lasprilla JC, Hincapíe L, ArcosBurgos M, Ossa JE, et al. (1997) Clinical features of earlyonset Alzheimer disease in a large kindred with an E280A presenilin-1 mutation. JAMA 277:793-799.

Negrette A (1963) Corea de Huntington. Segunda Edición. Talleres Gráficos de la Universidad del Zulia, Maracaibo.

Penchaszadeh VB (2004) Genetic services in Latin America. Community Genet 7:65-69.

Tagliani-Ribeiro A, Paskulin DD, Oliveira M, Zagonel-Oliveira M, Longo D, Ramallo V, Ashton-Prolla P, Saraiva-Pereira ML, Fagundes NJ, Schuler-Faccini L, et al. (2012) High twinning rate in Cândido Godói: A new role for p53 in human fertility. Hum Reprod 27:2866-2871.

\section{Internet Resources}

Human Development Report (2013) United Nations Development Programme (UNDP), http://hdr.undp.org/en/content/human-development-report-2013 (Retrieved on December 27, 2013).

Latin America and the Caribbean Population Database (2005) Centro Internacional de Agricultura Tropical, United Nations Environment Program, Center for International Earth Science Information Network, Columbia University, and the World Bank Latin American and Caribbean Population Database. Version 3, http://gisweb.ciat.cgiar.org/population/download/report.pdf (Retrieved on December 27, 2013).

Online Mendelian Inheritance in Man, http://www.ncbi.nlm.nih.gov/OMIM (Retrieved on December 27, 2013).

The World Bank (2013) Latin America \& Caribbean (developing only), http://data.worldbank.org/region/LAC (Retrieved on December 27, 2013).

License information: This is an open-access article distributed under the terms of the Creative Commons Attribution License, which permits unrestricted use, distribution, and reproduction in any medium, provided the original work is properly cited. 